\title{
Gold-quercetin nanoparticles prevent metabolic endotoxemia-induced kidney injury by regulating TLR4/NF-KB signaling and Nrf2 pathway in high fat diet fed mice [Retraction]
}

\begin{abstract}
Xu M-X, Wang M, Yang W-W. Gold-quercetin nanoparticles prevent metabolic endotoxemia-induced kidney injury by regulating TLR4/NF- $\mathrm{kB}$ signaling and Nrf2 pathway in high fat diet fed mice. International Journal of Nanomedicine. 2017:12;327-345.
\end{abstract}

At the request of the author, the Editor-in-Chief and Publisher of the International Journal of Nanomedicine wish to retract the published article.

Following a review of their data the authors observed some of the western blot bands for Figures 6, 10, 11 and 12 had been unintentionally duplicated. The specific duplications are:
- Western blot bands for Figure 6 SOD2 have been duplicated in the western blot bands for Figure 12 Keap1

- Western blot bands for Figure $10 \mathrm{NF}-\kappa \mathrm{B}$ have been duplicated in the western blot bands for Figure 11 GAPDH

It was determined by the authors the statistical differences indicated between the bands were no longer valid and the conclusions of the article were no longer supported.

Our decision-making was informed by our policy on publishing ethics and integrity and COPE's retraction guidelines. The authors wish to apologize for this error. 


\section{Publish your work in this journal}

The International Journal of Nanomedicine is an international, peerreviewed journal focusing on the application of nanotechnology in diagnostics, therapeutics, and drug delivery systems throughout the biomedical field. This journal is indexed on PubMed Central, MedLine, CAS, SciSearch ${ }^{\circledR}$, Current Contents ${ }^{\circledR} /$ Clinical Medicine,
Journal Citation Reports/Science Edition, EMBase, Scopus and the Elsevier Bibliographic databases. The manuscript management system is completely online and includes a very quick and fair peer-review system, which is all easy to use. Visit http://www.dovepress.com/ testimonials.php to read real quotes from published authors.

Submit your manuscript here: https://www.dovepress.com/international-journal-of-nanomedicine-journal 